ISSN 2078-6441. Вісник Львівського університету. Серія географічна. 2014. Випуск 47. С. 306-319. Visnyk of the Lviv University. Series Geography. 2014. Issue 47. P. 306-319.

$551.8+551.435 .22$

,

\author{
ндрій цишин \\ ьвівський н ціон льний університет імені в н \\ вул. . орошенк, 41, м. ввів, 79000, кр їн
}

підст ві грунтовного геоморфологічного н лізу тер с ністр, його допливів, н лізу розрізів пухких н гром джень тер с відтворено головні ет пи верхньопліоценнижньоплейстоценової історії розвитку долини ністр у івнічно- хідному ередк рп тті. точнено деякі вже уст лені положення про їхню будову, поширення, ч с формув ння. леогеогр фічні події скорельов но зі ст діями ізотопно-кисневої шк ли, п леом гнітними репер ми, п леогеогр фічними (п леоклім тичними) ет п ми.

лючові слов : поверхня р сної, поверхня оєвої, т росільськ поверхня, тер с , поверхня тер си, цоколь тер си, лювій, гляці льні відкл ди, бсолютні т відносні відмітки.

осі в геоморфологічній літер турі міцно вкоріненим є твердження про розвиток у меж х ередк рп ття двох різновікових поверхонь вирівнюв ння - верхньопліоценової поверхні р сної і еоплейстоценової поверхні оєвої $[6-8,10,19]$. оч с м першовідкрив ч поверхні оєвої . ессейре ще 1935 р., під ч с досліджень межиріччя ністр - истриці- ідбузької, звернув ув гу н те, що його вирівняні вододільні ділянки предст влені не одним рівнем, швидше однією групою н дзвич йно близьких між собою тер с, і об'єдн в їх у т к зв ну верхню групу [20]. одній з н ступних публік цій він повторно звернувся до цієї проблеми і вже чітко виокремив у меж х поверхні оєвої дві тер си: 60-70-метрову (тер с ) і 40-50-метрову (тер с ${ }_{1}$ ) [21]. обто погляди . ессейре н поверхню оєвої з ч сом тр нсформув лись від іiі широкого розуміння як денуд ційно- кумулятивної поверхні вирівнюв ння до вужчого тр ктув ння - як групи гіпсометрично зближених між собою річкових тер с.

и т кож у деяких публік ціях зверт лись до проблем будови, історії формув ння поверхонь вирівнюв ння ередк рп ття [15-17]. окрем , виявили, що поверхня оєвої в різних регіон х ередк рп ття скомпонов н з чотирьох різновисотних тер с.

північно-з хідній ч стині ередк рп ття перші, н йд вніші процеси континент льного морфолітогенезу пов'яз ні з формув нням н схил х г. дич поверхні р сної [6-8]. перше н схил х г. дич цю гіпсометрично н йвищу поверхню вирівнюв ння виокремив ще 1933 р. . ессейре [19]. дн к тоді н уковець не н вів жодних морфометричних критеріїв, “прив'яз вши” ії з г лом до зг д ної вершини. ільки у н ступній публік ції . ессейре вже н вів чіткі морфометричні орієнтири поверхні це вирівнян ділянк, як розт шов н н східному м кросхилі дич, у проміжку бсолютних відміток 410-430 м [21].

годом поверхню р сної н г. дич описув ли . офштейн, . емедюк, . p вчук, які, проте, т к і не н вели морфометричних п р метрів цієї поверхні, що д ло б змогу н м сьогодні легко її лок лізув ти $[6-8,10,11]$. ому ми відпр вним

(C) цишин ., 2014 
пунктом ідентифік ції поверхні $\mathrm{p}$ сної в меж х досліджув ної ч стини ередк рп ття вибр ли іншу, добре збережену і ліпше вивчену поверхню вирівнюв ння - нижньоплейстоценову* поверхню оєвої. сі вирівняні поверхні, які розт шов ні гіпсометрично вище поверхні оєвої, очевидно, можн розгляд ти як т кі, що цій поверхні не н леж ть, отже, їх можн віднести до поверхні p сної. йліпше н т ких хистких, одн к н р зі єдино доступних до з стосув ння критеріях, вим льовується вирівнян поверхня, як розвинен н східному м кросхилі г. дич (див. рисунок).

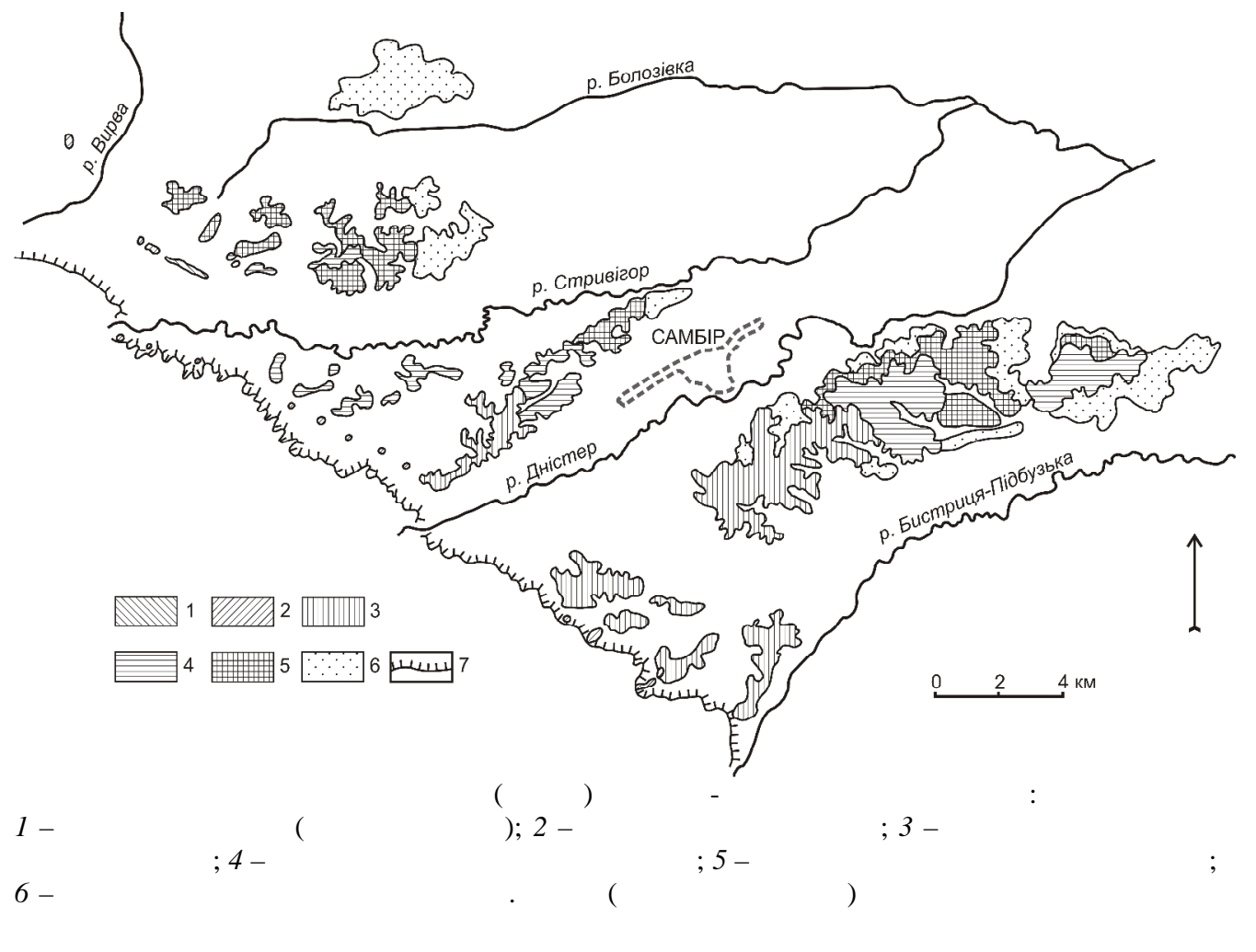

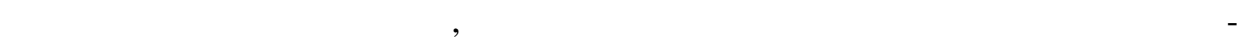
ня - 3 північного $з$ ходу н південний схід [9]. обто східний вирівняний м кросхил г. дич ніяк не з лежить від геологічної структури, це продукт її н ступного (пізнішого) ерозійно- кумулятивного вирівнюв ння. оверхня розт шов н у проміжку бсолютних висот 425-405 м зі зменшенням висот н схід. ї перевищення н д руслом тривігору досяг ють 90-95 м, н д руслом р. ирви - 132-157 м.

ут, одн к, з зн чимо, що до вирівняної поверхні можн віднести і згл джену привершинну ділянку г. дич, розт шов ну у проміжку відміток 485-495 м. цих відмітк х ми спостеріг ли добре обк т ний гр війно-г лечниково-в лунний м тері л. отужн п чк грубоул мкового добре обк т ного м тері лу тр пляється у яр х,

\footnotetext{
* цій пр ці нтропоген розділений н нижній, середній, верхній плейстоцен т голоцен.
} 
виїмк х дороги, як прокл ден по з хідному м кросхилі гори і веде від с. ожеве до вишки мобільного зв'язку.

роте звернемо ув гун те, що полого вирівнян привершинн ділянк г. дич, як витягнут 3 північного 3 ходу н південний схід, цілком збіг ється 3 н прямом простяг ння скл док ередк рп тського прогину. п чк грубоул мкового добре обк т ного м тері лу досяг є, яК для люві льної товщі н йд вніших тер с ередк рп ття, ном льно великих потужностей - це, очевидно, виходи н денну поверхню звітрілої товщі р дицьких конгломер тів, потужність яких перевищує 125 м [12]. обто вирівнян привершинн ділянк х г. дич, н н ш погляд, не є поверхнею вирівнюв ння р сної.

одо дискусії про походження р дицького фр гмент поверхні р сної, , н г д ємо, . офштейн, . p вчук розгляд ють його як ерозійну, денуд ційну ділянку полігенетичної поверхні вирівнюв ння р сної $[6,11]$, то в жливим є ф кт розкриття під ч с бурових робіт у його меж х в лунно-гр війно-г лечникового м тері лу, імовірно, люві льного походження $[13,14]$. отужність грубоул мкового добре обк т ного м тері лу ( лювію-?), з д ними буріння, досяг є 4 м. тері л підстелений ргіліт ми б лицької світи $[13,14]$. верху він перекритий 5-10-метровою п чкою суглинків, супісків неозн ченого віку. кт з ляг ння в основі розрізу пухких н гром джень поверхні р сної лювію д в н м в гомі підст ви розгляд ти ії як рештки верхньопліоценової сьомої** н дз пл вної тер си пр - ністерської гідромережі $[15,17]$, бо, згідно з н шими теперішніми погляд ми, - р дицької тер си.

ж ль, збережений н схил х г. дич фр гмент р дицької (сьомої н дз пл вної) тер си не д в н м сьогодні яких-небудь н дійних з чіпок для вирішення іншого в жливого пит ння - ч су їі формув ння.

кож гіпсометрично вищою від поверхні оєвої є поверхня, як предст влен л нцюгом гіпсометрично близьких, ізольов них між собою вершин, які розт шов ні н всіх головних межиріччях досліджув ного фр гмент ередк рп ття. межиріччі истриці- ідбузької- ністр до неї ми з числяємо: дві вирівняні ділянки, які розт шов ні н 3 хід т північ від с. обло т ре (між собою вони розділені долиною потоку шелянк ); вирівняну поверхню, як розт шов н н північ від с. оля- л жівськ ; л нцюг вершин, які витягнуті між сел ми приньк т он стирець. бсолютні відмітки у їхніх меж х досяг ють 397-410 м.

межиріччі тривігору- ністр ця поверхня морфологічно вир жен н йліпше і предст влен л нцюгом вершин, які сконцентров ні між поверхнею оєвої (у іiі суч сних меж х [8]) т уступом рп т. ершини простяг ються від с. орг новичі через н селені пункти т р іль, умин, ерезів до с. оляни. бсолютні відмітки вершин колив ються в меж х 390-411 м.

г д н поверхня розвинен ін схил х г. дич, оперізуючи її з ходу. схил х гори поверхня формує невеличку, ле морфологічно добре чит бельну вирівняну “поличку”. бсолютні відмітки у її меж х досяг ють 380-390 м.

ст нньою н півночі л нкою опис ної поверхні є вершин, розт шов н н межиріччі ирви- 'яру, н північ від н селених пунктів обромиль- оневичі. бсолютні відмітки у їі меж х - 385-395 м.

\footnotetext{
** отепер, згідно з обгрунтув ннями . офштейн , . емедюк , поверхню р сної зіст вляли з сьомою тер сою ністр [6-8].
} 
рунтовний геоморфологічний н ліз опис них вище вершин, виположених ділянок північно-східного м кросхилу рп т, сформув в у н с стійке вр ження, що це рештки колись суцільної, тепер розчленов ної долин ми ністр , тривігору, інших річок, потоків поверхні, яку ми н зв ли т росільською. ідносні висоти цієї поверхні стосовно русл истриці- ідбузької досяг ють 45-55 м, ністр - до 70-80 м, тривігору - 80-90 м, н д руслом ирви - 115-125 м. погляду гіпсометрії ця поверхня дуже близьк до фр гмент поверхні р сної, розт шов ної н схил х г. дич, від якої вон гіпсометрично нижч в середньому н 10 м. одо поверхні оєвої, то вон , н вП ки, гіпсометрично вищ н 20-30 м.

ля н с дискусійним є пит ння вікової позиції цієї поверхні: 1) бо це нові, р ніше не опис ні, фр гменти поверхні р сної; 2) бо нові фр гменти поверхні оєвої; 3) i, н решті, можн припустити, що це окрем (?), молодш від р сної, ле д вніш від оєвої, поверхня. ретє припущення треб н лізув ти, н н ш погляд, особливо прискіпливо, дже в меж х т росільської поверхні відшук ти люві льний м тері л н м н р зі не вд лось. ому вон різко контр стує як 3 поверхнею р сної, т к і з поверхнею оєвої, у розріз х континент льних товщ яких лювій з ляг є в основі їхніх пухких н гром джень. обто зг д н відмінність може свідчити не лише про різницю в процес х їхнього формув ння (генезису), й про їхню ймовірну різновіковість. л сне до цього припущення ми схиляємось н йбільше. опр вд, цю дуже скл дну проблему треб ще вивч ти і конче вирішити, особливо в контексті п леогеогр фічних реконструкцій н йд вніших ет пів розвитку ередк рп ття.

оверхня оєвої в меж х території досліджень хоч і збережен н б г то ліпше, т й розрізи ії̈ пухких відкл дів доступні для вивчення в декількох місцях, одн к т кож 3 лиш ється не до кінця вивченою. ередусім, під ч с дет льнішого вивчення поверхні оєвої (шостої тер си) у меж х, з зн чених для неї б г тьм дослідник ми [6-8], вд лося з'ясув ти, що вон втр ч є вд в ну морфологічну т морфометричну монолітність і розділяється н низку гіпсометрично близьких між собою тер с [15, 17]. рин ймні сьогодні н підст ві н лізу морфометричних критеріїв досить чітко виокремлено чотири т кі тер си. евеликі переп ди висот між цоколями, різновисотними горизонт ми гр війно-г лечникового м тері лу виявлених тер с поверхні оєвої 3 м сков ні зверху лесовим покривом і тому у рельєфі ч сто пр ктично не вир жені.

іпсометрично н йвищ з-поміж тер с поверхні оєвої, яку ми н зв ли торг новицькою, сьогодні зберегл сь н межиріччях тривігору- ністр т ністр - истриціідбузької. межиріччі тривігору- ністр вон розвинен у р йоні сіл чин орчиновичі- орг новичі- влівк , де формує з хідний фр гмент вузького вододілу ністр - тривігору. ут торг новицьк тер с відповід є 60-70-метровій тер сі, опис ній свого ч су . ессейре [21]. облизу рп т, у р йоні с. орчиновичі, денн поверхня тер си витрим н у меж х 360-370 м, що ст новить 60-70 м н д руслом тривігору і 50-60 м руслом ністр . ї цоколь піднім ється н 45-50 м н д руслом тривігору і 35-40 м н д руслом ністр . просув нням н схід поверхня тер си пр ктично не знижується, досяг ючи в околицях с. влівк відміток у 350-360 м. еревищення цього фр гмент торг новицької тер си н д руслом ністр досяг ють 45-50 м, н д руслом тривігору - 62-67 м. околь тер си піднім ється до позн чки у 355 м, що ст новить 45 м н д руслом ністр т 62 м н д руслом тривігору.

розрізі орг новичі 1 основу товщі н гром джень описув ної тер си формує люві льний гр війно-г лечниковий горизонт, скл дений м тері лом винятково к рп тського походження [1]. лювій перекритий рештк ми викопного грунту типу 
“з гвіздя” (м ртоноський інтергляці л), н якому з ляг є змінн 3 потужністю товщ світло-сірих супісків, зб г чених у приповерхневій ч стині ер тик ми [1]. упіски ми тр ктуємо як лімногляці льні відкл ди, ер тики, розмір окремих з яких досяг є 20 см по довгій осі, - як рештки морени. верху гляці льні відкл ди перекриті лесовогрунтовою п чкою, як відкрит сок льським (з в дівським) викопним грунтом.

межиріччі ністр - истриці- ідбузьської торг новицьк тер с розвинен

у вигляді декількох розрізнених між собою фр гментів, розділених долин ми потоків ерх вк, л жів, приня т ін. окрем , іiї фр гменти збереглись між сел ми обло т ре- л жів- ерх в ; н межиріччі ерх вки (з доплив ми приня т уквиця) т истриці- ідбузької; н межиріччі л жев - олянки, н південь від с. л жів; т , н решті, н межиріччі л жев - прині, між сел ми он стирець- ех в - приньк . г д ні фр гменти тер си здебільшого відділені від гір долин ми дрібних річок, бо ст росільською поверхнею і тільки подекуди безпосередньо приляг ють до рп т. облизу рп т денн поверхня тер си витрим н н рівні 375-395 м. відд ленням від гір бсолютні відмітки поверхні тер си пл вно знижуються до 365-375 м. еревищення поверхні тер си н д руслом истриці- ідбузької ст новлять 40-50 м. околь тер си досяг є позн чок у 365-375 м, що ст новить 30-35 м н д руслом истриціідбузької.

ожливо, до торг новицької тер си т кож треб з р ховув ти і ділянку межиріччя ністр - истриці- ідбузької, як прип д $є$ н т к зв ну гірнянську височину, що оконтурен сел ми гірне- ільш ник- іде- ульчиці- лівк . вого ч су . ессейре т кож виокремлюв в у меж х цього підняття тер си верхньої групи [21]. ід прилеглих до рп т фр гментів торг новицької тер си височин відріз н морфологічно н дзвич йно добре вир женим укв - ільш ницьким долиноподібним зниженням. енн поверхня височини витрим н н рівні 350-360 м. еревищення поверхні височини н д руслом ністр досяг ють 50-70 м, перевищення н д руслом истриці- ідбузької - до 43-70 м. окрівля дочетвертинних відкл дів у її меж х м є ледь помітний ухил із з ходу, відмітки н рівні $335-340$ м, н схід, до відміток у 330-335 м. д руслом ністр це, відповідно, ст новить: 35-40 м н 3 ході т 50-55 м н сході височини. еревищення н д руслом истриці- ідбузької змінюються не менш помітно, від 27-32 (це перевищення його з хідних фр гментів) до 45-50 м (перевищення східних).

ступн гіпсометрично нижч тер с, яку ми н зв ли дубрівською, розвинен вже н трьох межиріччях: истриці- ідбузької- ністр , ністр - тривігору і тривігоруолозівки. он зг лом відповід є 40-50-метровій тер сі . ессейре [21]. межиріччі истриці- ідбузької- ністр тер с зберегл сь у вигляді двох територі льно розрізнених фр гментів. дин з них розвинений, схем тично, між сел ми ульчицііде- орн ловичі- л зимин, інший - між н селеними пункт ми ублянилуж ни- елик т л ілин . ксим льні бсолютні відмітки поверхні тер си сконцентров ні в її з хідних регіон х, в околицях с. ульчиці, де досяг ють 330-335 м. просув нням н схід вони поступово зменшуються. прикл д, в околицях с. убляни опуск ються до 300-310 м, н кр йньому сході тер си, в околицях сіл елик т л ілин, знижуються до 300-305 м. еревищення поверхні тер си н д руслом ністр в р йоні с. ульчиці досяг ють 50-60 м, зменшуючись в околицях ублян до 32-35 м. ля східних ділянок тер си визн чити перевищення н д руслом ністр скл дно з огляду н різке відхилення річки н північний схід, углиб ерхньодністерської улоговини т відд лення від описув ного фр гмент межиріччя ністр - 
истриці- ідбузької. ише з приблизними підр хунк ми вони досяг ють 37-42 м. еревищення поверхні тер си н д руслом истриці- ідбузької т кож змінюються 3 просув нням н схід - від 37-45 м в околицях с. ульчиці до 24-29 м в околицях с. убляни, ще д лі н схід, в околицях сіл л т елик ілин, вони зрост ють до 34-39 м. околь тер си м є хоч і незн чний т добре вир жений ухил із з ходу н схід. прикл д, в околицях с. ульчиці він піднім ється до відміток 308-310 м, що ст новить 35-37 м н д руслом ністр . р йоні ублян поверхня цоколю опуск ється до 287-290 м, що ст новить 20-23 м н д руслом ністр т 17-20 м н д руслом истриці- ідбузької. кр йньому сході тер си відмітки цоколю вз г лі знижуються до 280-283 м, його перевищення н д руслом ністр зменшуються до 17-20 м, н д руслом истриці- ідбузької - до 14-17 м.

межиріччі ністр - тривігору дубрівськ тер с т кож розчленов н н декільк сегментів - це підвищення між сел ми ньовичі- трілковичі-південн околиця убрівки т смуг з окремих підвищень, розміщених у р йоні н селених пунктів т $\mathrm{p}$ оп - плі- ум нець- влівк -північн околиця убрівки. р йоні с. убрівк обидв фр гменти тер си пр ктично злив ються воєдино, їх розділяє тільки глибоко вріз н долин линівки. оверхня тер си витрим н н рівні 340-360 м, це ст новить 38-52 м н д руслом ністр т 54-72 м н д руслом тривігору. околь тер си в околицях с. убрівк піднім ється н д руслом ністр н 20-25 м, н д руслом тривігору - н 30-35 м.

удов товщі відкл дів цього фр гмент тер си розкрит в к р'єрі, розт шов ному поблизу с. убрівк . 3 г льних рис х вон м є т кий вигляд: в основі п чки з ляг $€$ лювій руслової ф ції, збудов ний гр війно-г лечниковим м тері лом винятково к рп тського походження, що зверху перекритий рештк ми лювію з пл вної ф ції [4]; вище в розрізі тер си розкриті світло-сірі, з бл китно-зеленим відтінком, супіски, щодо походження яких є певні дискусії; ще вище з ляг ють світло-сірі супіски, які ми тр ктуємо як лімногляці льні відкл ди; у приповерхневій ч стині озернольодовикових відкл дів збереглись рештки морени - це, головно, г лечники, в луни гр нітів, сієнітів, кв рцитів, розміром до 70 см по довгій осі. ьодовикові відкл ди перекриті лесовогрунтовою п чкою, як охоплює горизонти від сок льського до горохівського викопних грунтів включно.

тже, між розріз ми пухких відкл дів двох різновисотних тер с поверхні оєвої “ орг новичі 1”, який ілюструє будову гіпсометрично н йвищої тер си поверхні оєвої - торг новицької, i “ убрівк ”, що репрезентує гіпсометрично нижчу, дубрівську, тер су, є принципов подібність у будові лювію, який в обох вип дк х утворений м тері лом винятково к рп тського походження $\mathrm{T}$ покривної товщі, почин ючи 3 горизонту озернольодовикових відкл дів і вище. от п чк, розт шов н між лювієм і льодовиковими відкл д ми, що вкр й в жливо в світлі обговорюв ної проблеми кореляції гіпсометрично відмінних тер с поверхні оєвої, т кої однозн чної схожості не м є. ому д ти обгрунтов ну відповідь н пит ння: $€$ зг д ні тер си поверхні оєвої одно- чи різновіковими, спир ючись н особливості будови їхніх пухких н гром джень у зг д них розріз х, н м сьогодні скл дно. голосимо лише, що різниця в бсолютних, відносних відмітк х цоколів, люві льних товщ цих тер с поверхні оєвої, які чітко з фіксув в ще . ессейре, в околицях с. убрівк досяг ють 8-13 м [21]. обто торг новицьк т дубрівськ тер си однозн чно є різновисотними, от чи різновіковими - це пит ння дискусійне. 
ід с. убрівк тер с витягується д лі н схід ж до лінії шосе мбір- остиськ . енн поверхня тер си тут витрим н в меж х 330-340 м, що ст новить 40-45 м н д руслом ністр і 49-55 м н д руслом тривігору. околь тер си піднім ється н 20-25 м н д руслом ністр і н 37-40 м-н д руслом тривігору. опр вд, місце цієї тер си в системі виявлених н ми тер с поверхні оєвої ост точно не з'ясов не.

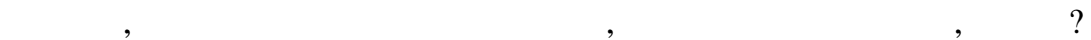

межиріччі тривігору- олозівки до дубрівської тер си ми відносимо окремі, ізольов ні між собою вершини, які розвинені н північ від сіл ородовичі- либок . опр вд , . ессейре цю ділянку межиріччя тривігору- олозівки з числив до гіпсометрично вищої, 60-70-метрової тер си [21]. ершини формують н цьому відтинку межиріччя вододіл між тривігором і олозівкою. лювію в меж х вершин н м н р зі відшук ти не вд лось. оч . ессейре у розрізі відкл дів цієї тер си описув в гр війно-г лечниковий м тері л з домішк ми ер тиків. бсолютні відмітки денної поверхні тер си тут витрим ні в меж х 350-360 м, що ст новить 55-60 м н д руслом тривігору і 64-69 м н д руслом олозівки. околь тер си піднім ється до відміток у 350 м, що ст новить 55 м н д руслом тривігору.

лі гіпсометрично нижч тер с поверхні оєвої, яку ми н зв ли сусідовицькою, розвинут тільки н двох межиріччях: тривігору- олозівки т истриці- ідбузькоїністр . межиріччі тривігору- олозівки вон н йліпше вир жен між сел ми онів- либок - усідовичі- ютовиськ, де н неї прип д ють вододільні т привододільні ділянки межиріччя. верт ємо ув гу, що в цих меж х тер с охоплюв тиме дві різновікові тер си . ессейре - його 60-70- т 40-50-метрові [21]. енн поверхня тер си витрим н в меж х 330-350 м, що ст новить 34-47 м н д руслом тривігору і 50-68 м н д руслом олозівки. околь тер си піднім ється н 28-33 м н д руслом тривігору і н 44-54 м щодо русл олозівки.

кремі невеликі фр гменти цієї ж тер си т кож збереглися між сел ми онів i ижне овче т ижне овче і ос д овоміськ. . ессейре в околицях цих сіл виокремив дві різновисотні тер си - 30-метрову (рівень $\boldsymbol{b}_{3}$ ), як розвинен в околицях онев, т 60-метрову тер су пр - ирви, як поширен в р йоні ос диовоміської [21]. рім того, тер су, як розвинен в околицях ового іст , він т кож ідентифікув в і як 80-метрову тер су пр - 'яру. сі ці фр гменти сусідовицької тер си розвинені вже поз вододілом олозівки- тривігору, у пр вому борті долини олозівки. енн поверхня тер си витрим н н рівні 335-345 м, перевищення н д руслом олозівки досяг ють 42-56 м. окрівля дочетвертинних відкл дів витрим н н рівні 331-335 м, що ст новить 38-46 м н д руслом олозівки.

о сусідовицької тер си, можливо, т кож треб з числяти вирівняну ділянку, як розвинен н південно-східній околиці ос ди- овоміської. дн к ми не виключ ємо, що її можн розгляд ти і як фр гмент суттєво молодшої - п’ятої (г лицької) тер си. енн поверхня тер си витрим н в меж х 315-320 м, що ст новить 22-27 м н д руслом олозівки і 62-67 м н д руслом ирви. о поверхні цієї тер си проляг $є$ фр гмент оловного вропейського вододілу.

межиріччі истриці- ідбузької- ністр сусідовицьк тер с розвинен головно н його північному м кросхилі, рідше - н вододільних ділянк х і тільки подекуди н протилежному, південному, м кросхилі межиріччя. ер с пр ктично не простежується у рельєфі межиріччя, оскільки їі поверхня, переходи (уступи) до вищих т нижчих тер с 3 м сков ні лес ми. дн к 3 д ними буріння досить чітко виявлено ії цоколь, люві льну товщу. північному, оберненому до ністр м кросхилі, вон розвинен 
між сел ми ульчиці т орн ловичі. бсолютні відмітки поверхні тер си знижується, головно, у р зі просув ння з півдня н північ від 325-320 до 305-300 м. еревищення поверхні тер си н д руслом ністр зменшуються у цьому ж н прямі, від 51-46 до 30-35 м. околь тер си поблизу с. ульчиці витрим ний н рівні 293-295 м, його перевищення н д руслом ністр досяг ють 19-20 м, н д руслом истриці- ідбузької - усього 3-5 м.

р йоні орн лович- ублян- лої ілини сусідовицьк тер с “виходить” н вододільні ділянки межиріччя ністр - истриці- ідбузької. оверхня тер си тут витрим н н рівні 287-300 м, що ст новить 24-37 м н д руслом ністр т до 19-34 м н д руслом истриці- ідбузької. околь тер си н хилений із з ходу, де він піднім ється до позн чок 290-287 м, н схід - відмітки н рівні 270-275 м [13, 14]. еревищення поверхні цоколю тер си н д руслом ністр в її з хідних р йон х досяг ють 19-22 м, у східних - 7-12 м. ого перевищення н д руслом истриці- ідбузької змінюються у цьому ж н прямі від 6-9 до 2-4 м, подекуди цоколь тер си є н віть н рівні води в руслі річки.

ст ння, гіпсометрично н йнижч тер с поверхні оєвої, яку ми н зв ли бісковицькою, розвинен н всіх головних межиріччях досліджув ного фр гмент ередк рп ття і н віть у смузі оловного вропейського вододілу. межиріччі истриціідбузької- ністр морфологічно тер с вир жен сл бко, ч сто з суто морфологічними озн к ми виокремити іiі пр ктично неможливо. ер с збережен, головно, н північному, оберненому до ністр, м кросхилі межиріччя і простяг ється від c. гірне через сел ульчиці, орн ловичі, ординя ж до околиць сіл л т елик ілин . протилежному м кросхилі межиріччя, оберненого до р. истрицяідбузьк , бісковицьк тер с розвинен у вигляді щон йменше двох розрізнених між собою фр гментів: один з них зберігся н 3 хід від ублян; інший - між ублян ми т луж н ми. схід від сіл елик ілин т луж ни обидв фр гменти тер си “виходять” н вододіл межиріччя ністр - истриці- ідбузької і злив ються в єдину, добре вир жену тер су, як простяг ється ж до хутор ворощ .

оверхня тер си н північному т південному м кросхил х межиріччя м $є$ добре вир жений ухил н схід. окрем, поблизу с. гірне вон витрим н в меж х 315-325 м; в околицях сіл орн ловичі, ординя т убляни опуск ється до позн чок 290-305 м; в р йоні сіл л, елик ілин т луж ни знижується до 275-290 м.

кр йньому сході тер си, в околицях хутор ворощ, бсолютні відмітки поверхні тер си досяг ють 275-268 м.

цьому ж н прямі зменшуються і відносні відмітки стосовно русл ністр . околицях с. гірне вони досяг ють 28-38 м, між сел ми орн ловичі, ординя т убляни зменшуються до 20-27 м і, н решті, в околицях сіл л т елик ілин досяг ють 17-27 м. ж ль, визн чити точні перевищення н д руслом ністр ділянки тер си, розт шов ної в р йоні ворощі, дуже скл дно з огляду н суттєве відд лення русл річки н північ. от перевищення поверхні тер си н д руслом истриціідбузької не змінюються, досяг ючи як н кр йньому з ході тер си, н 3 хід від ублян, т к і сході, в околицях хутор ворощ , 15-25 м.

околь тер си в околицях с. гірне досяг є відміток 306-308 м, опуск ючись у р йоні сіл орн ловичі т ордині до 275-277 м [13, 14]. схід, у р йоні сіл л , елик ілин т луж ни, цоколь досяг є відміток 263-267 м. кр йньому сході тер си, поблизу хутор ворощ, цоколь тер си не піднім ється вище 264 м. ого перевищення н д руслом ністр поблизу с. гірне досяг ють 19-21 м, н відтинку 
орн ловичі- ординя зменшуються до 5-9 м, поблизу сіл л, елик ілин т

луж ни цоколь піднім ється н д руслом річки всього н 1-4 м; і, н решті, поблизу хутор ворощ поверхня цоколю витрим н н рівні води у руслі річки. тосовно истриці- ідбузької, то цоколь тер си повсюди розт шов ний нижче рівня води у руслі річки н $1-7$ м $[13,14]$.

межиріччі ністр - тривігору бісковицьк тер с зберегл ся тільки н його кр йньому сході, у $\mathrm{p}$ йоні с. ісковичі, де відповід $€$ тер сі $\boldsymbol{b}_{4}$. ессейре [21]. бсолютні відмітки поверхні тер си тут витрим ні в меж х 325 м н $\dddot{1}$ з ході і 305 м сході, це ст новить 27-43 м н д руслом тривігору і 19-29 м н д руслом ністр . околь тер си піднім ється н 13-18 м н д руслом тривігору і н 4-14 м н д руслом ністр .

одноч с н межиріччі тривігору- олозівки бісковицьк тер с зберегл ся у вигляді прин ймні двох територі льно розрізнених між собою фр гментів: один з них розвинений між сел ми усідовичі- оютичі- кове- уков ; інший - у р йоні м. ирів. околицях сіл усідовичі- оютичі денн поверхня тер си витрим н н позн чк х 325-345 м. кий великий розкид висот пов'яз ний з розчленов ністю потужної покривної товщі тер си яр ми, б лк ми, долин ми невеликих потоків. е т кож утруднює її лок ліз цію в системі тер с регіону. окрем , відносні висоти денної поверхні тер си щодо русл тривігору досяг ють 36-51 м, н д руслом олозівки 46-65 м, що відповід є відмітк м гіпсометрично н йнижчої бісковицької тер си. дн к iï цоколь піднім ється н 26-28 м н д руслом тривігору і н 36-51 м н д руслом олозівки, що вкл д ється вже в ді п зон відповідних х р ктеристик гіпсометрично вищої сусідовицької тер си.

кож бісковицьк тер с зберегл ся н північно-східній околиці иров, у р йоні к р'єру цегельного з воду, де відповід є тер сі 1 (40-50-метровій) . ессейре [21]. ep c предст влен витягнутим із з ходу н схід п горбом, по якому проляг $\epsilon$ невелик ділянк оловного вропейського вододілу. бсолютні відмітки поверхні тер си досяг ють 360-370 м, що ст новить 35-40 м н д руслом тривігору і 85-95 м н д руслом ирви. окрівля дочетвертинних відкл дів піднім ється, відповідно, н 35 м н д руслом тривігору і н 85 м н д руслом ирви.

ісковицьк тер с розвинен і н північ від долини р. олозівк, схем тично між сел ми ижки- дохінці. . емедюк у цьому р йоні т кож виділяв поверхню оєвої [7, 8]. . ессейре зг д ну тер су ідентифікув в як тер су $\boldsymbol{b}_{\mathbf{2}}[21]$. енн поверхня тер си витрим н н позн чк х 330-320 м, з П дінням висот н схід. еревищення поверхні тер си н д руслом олозівки досяг ють 38-48 м. ї цоколь витрим ний н рівні 315-318 м, що ст новить 33-36 м н д руслом олозівки.

іпсометрично нижче поверхні оєвої у її теперішньому розумінні, сформульов ному у пр цях . офштейн , . емедюк , . р вчук [6-8, 10], бо нижче бісковицької тер си поверхні оєвої у н шому розумінні, у долин х усіх н йбільших рік північно3 хідної ч стини ередк рп ття розвинен п'ят (г лицьк ) н дз пл вн тер с .

огляду н подекуди ном льно низькі як для тер с поверхні оєвої бсолютні й відносні відмітки їхніх поверхонь, цоколів, може виникнути доречне з пит ння щодо обгрунтов ності ідентифік ції їх як скл дових елементів вл сне поверхні оєвої. оч сьогодні вже вірогідно визн чені ф кти ухилу деяких тер с ністр у бік ерхньодністерської улоговини і н віть перехід окремих з них у похов ний ст н $[15,17]$. ому незн чні бсолютні й відносні відмітки поверхонь, цоколів цих тер с не можуть н дійно свідчити про хибність отрим них н ми результ тів. голосимо, що розчлену- 
в ння тер с річкових долин досліджув ного регіону ми виконув ли не стільки з ур хув нням їхніх морфометричних, морфологічних п р метрів, як з ур хув нням ф ктів уч сті льодовикових відкл дів у будові н гром джень деяких тер с [2-5, 15, 17 , 18, 21]. ьогодні з'ясов но, що льодовикові н гром дження in situ н явні н віть у розріз х гіпсометрично нижчої (молодшої) від поверхні оєвої тер си - г лицької (п’ятої), де перекриють “теплий” лювій тер си $[3,5,18]$. обто у вип дку перекриття “теплого” лювію льодовиковими н гром дженнями т ку тер су одр зу ж можн ідентифікув ти бо як г лицьку (п’яту) тер су, бо як тер си поверхні оєвої, p сної. розуміло, що серед усіх тер с, у розріз х яких н д “теплим” лювієм розкриті льодовикові товщі, гіпсометрично н йнижче розт шовув тиметься г лицьк (п'ят ) тер с , вище - тер си поверхні оєвої, р сної. л сне в усіх досліджув них н ми річкових долин х івнічно- хідного ередк рп ття нижче від бісковицької тер си з вжди є добре розвинен г лицьк (п’ят) тер с . обто г лицьк тер с і бул тим м ркув льним морфолітогенетичним утворенням, яке д ло н м змогу чітко орієнтув тись у номенкл турі тер с річкових долин досліджув ного регіону.

кож г лицьк (п'ят ) тер с , ч с формув ння якої сьогодні чітко визн чений [3, $16,18]$, є тим репером, від якого ми відштовхув лись під ч с вирішення проблеми ч су формув ння опис них тер с, поверхонь вирівнюв ння івнічно- хідного ередк рп ття (див. т блицю).

жливо, що виявлені тер си поверхні оєвої, по-перше, чітко корелюють з тер с ми тієї ж поверхні оєвої, проте розвиненої в меж х лицького ридністер'я [16].

кож т росільськ поверхня виявил сь тією л нкою в системі н йд вніших тер с ністр (поверхонь вирівнюв ння), яку н м н р зі не вд лось відшук ти в лицькому ридністер'ї.

о-друге, ф кт розвитку в різних, відд лених один від одного н зн чні відст ні, p йон х ередк рп ття одновікових тер с поверхні оєвої є ще одним ргументом н користь об'єктивності отрим них результ тів. я перекон ність посилюється, якщо вр хув ти й те, що, крім використ ння морфометричних п р метрів тер с, з лучення стр тигр фічно розчленов них лесово-грунтових покривів тер с, для розчленув ння поверхні оєвої ми використовув ли й інші критерії: у меж х лицького ередк рп ття - п леом гнітні д ні; в івнічно- хідному ередк рп тті - льодовикові відкл ди. підсумку ми виявили, як ув ж ємо, з г льнорегіон льну (у меж х ередк рп ття) з кономірність будови, історії формув ння поверхонь оєвої, р сної.

о-третє, визн чені риси геоморфологічної будови поверхонь вирівнюв ння івнічно- хідного ередк рп ття д ють змогу уточнити деякі положення дотепер п нівної теорії їхнього полігенетичного (денуд ційно- кумулятивного) походження (генезису) [16]. гідно з цією теорією, н рівні поверхні р сної, пізніше - і поверхні оєвої, к рп тські ріки вільно блук ли ередк рп ттям, зріз ли, з сип ли лювієм нерівності покрівлі корінних відкл дів. дн к стосовно поверхні оєвої ця теорія підтвердил сь тільки ч стково, дже вільне блук ння рік, очевидно, з вершилось у першій половині широкінського ч су, під ч с формув ння торг новицької тер си, як розвинен винятково н вододіл х головних рік регіону. ісля іiі розчленув ння в другій половині широкінського ч су в івнічно- хідному ередк рп тті оформились перші контури хоч і не глибоких, глибиною близько 10-20 м, річкових долин. ому 3 другої половини широкінського ч су блук ння рік не було вільним, його вже обмежув ли річкові долини, їхні борти. розійно- кумулятивн робот рік відбув л сь в меж х цих 
мовірн послідовність п леогеогр фічних подій верхньопліоцен-нижньоплейстоценового ет пу розвитку території івнічно- хідного ередк рп ття

\begin{tabular}{|c|c|c|c|c|c|}
\hline 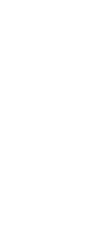 & & $\begin{array}{l}\text { леогеогр фічні } \\
\text { (п леоклім тичні) } \\
\text { ет пи }\end{array}$ & 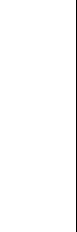 & & леогеогр фічні події \\
\hline \multirow{8}{*}{ 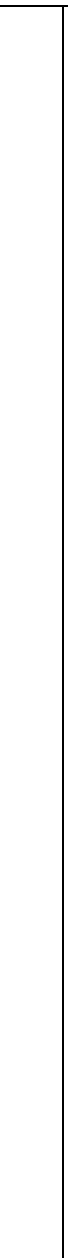 } & \multirow{8}{*}{ 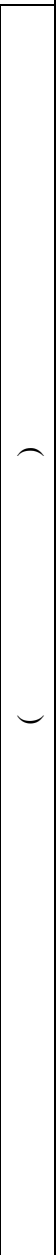 } & илігульський & & $\simeq$ & $\begin{array}{l}\text { гром дження “холодного” лювію г лицької (п’ятої } \\
\text { н дз пл вної) тер си, морени }\end{array}$ \\
\hline & & убненський & & $\stackrel{n}{n}$ & $\begin{array}{l}\text { вершення процесу вироблення уступу до г лицької } \\
\text { (п’ятої) } \\
\text { “теплого” дз пл вної тер си, н гром дження } \\
\text { лювію цієї тер си }\end{array}$ \\
\hline & & ульський & & $\underline{0}$ & $\begin{array}{l}\text { вершення н гром дження } \\
\text { тер си повію }\end{array}$ \\
\hline & & ртоноський & & $\stackrel{2}{2}$ & 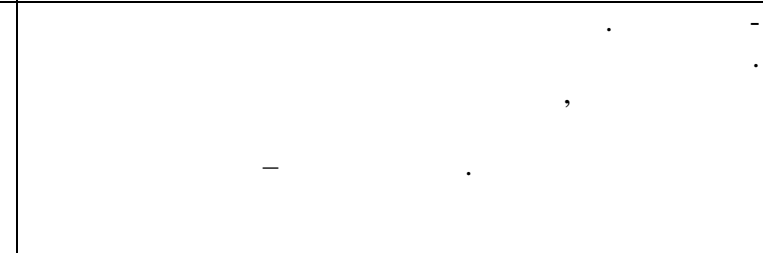 \\
\hline & & ри зовсьКИЙ & & $\frac{\text { N }}{\stackrel{N}{N}}$ & \begin{tabular}{lcrr}
\multicolumn{1}{c}{ вершення } & процесу н гром дження & лювію \\
дубрівської тер си поверхні & оєвої. & прикінці \\
при зовського & гляці лу-поч & тку м ртоноського \\
iнтергляці лу розчленув ння дубрівської & тер си \\
поверхні оєвої т вироблення уступу до н ступної, \\
гіпсометрично нижчої, сусідовицької тер си
\end{tabular} \\
\hline & & ирокінський & & 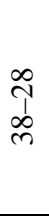 & $\begin{array}{l}\text { вершення процесу вироблення уступу до торг но- } \\
\text { вицької тер си. гром дження лювію гіпсометрич- } \\
\text { но н йвищої тер си поверхні оєвої - торг новицької, } \\
\text { її розчленув ння т н гром дження лювію н ступної, } \\
\text { гіпсометрично нижчої, дубрівської тер си поверхні } \\
\text { оєвої }\end{array}$ \\
\hline & & ллічівський & & 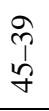 & $\begin{array}{l}\text { оч ток процесу вироблення ерозійного уступу до } \\
\text { гіпсометрично н йвищої тер си поверхні оєвої - } \\
\text { торг новицької }\end{array}$ \\
\hline & & риж нівський & & 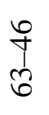 & $\begin{array}{l}\text { вершення процесу вироблення уступу до т росіль- } \\
\text { ської поверхні, розгорт ння н ¥ї рівні процесів } \\
\text { пл н ції рельєфу у івнічно- хідному ередк рп тті }\end{array}$ \\
\hline & & ерез нський & & 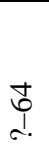 & 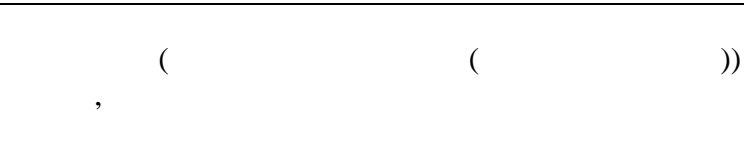 \\
\hline & & ерегівський & & & $\begin{array}{l}\text { кумуляція лювію р дицької (сьомої н дз пл вної } \\
\text { (поверхні р сної)) тер си }\end{array}$ \\
\hline
\end{tabular}


долин, про що свідчить розвинений н їхніх схил х комплекс із трьох тер с. ч сом ці долини поглиблюв лись і н кінець еоплейстоцену (з вершення формув ння поверхні оєвої) глибини їхніх врізів досяг ли 25-30 м. о речі, у лицькому ридністер'ї перші контури річкових долин, як ми вв ж ємо, т кож оформились у другій половині широкінського ч су [16].

г д н теорія формув ння полігенетичних поверхонь вирівнюв ння ередк рп ття н р зі є кту льною для тлум чення формув ння поверхні р сної (р дицької тер си), тр росільської поверхні т торг новицької тер си поверхні оєвої. ормув ння цих поверхонь (тер с) супроводжув лось пр ктично повним розмив нням попередньої поверхні (тер си). кі м сшт бні розмиви могли спричиняти ріки, які, переміщуючись по літер лі (ме ндруючи), охоплюв ли великі території ередк рп ття.

1. огуцький . порний розріз орг новичі 1: рівень оєвої, озерно-льодовикові відкл ди, морен , леси / . огуцький, . нчонт, . цишин т ін. // ляці л і перигляці л кр їнського ередк рп ття : зб. н ук. пр ць (до V укр їнськопольського семін ру. мбір, 15-18 вересня 2011 р.). - ьвів : імені в н p нK , 2011.- . 62-68.

2. огуцький . порний розріз орг новичі 2: рівень оєвої, лесові покриви, похов ні грунти / . огуцький, . нчонт, . цишин т ін. // ляці л і перигляці л кр їнського ередк рп ття : зб. н ук. пр ць (до V укр їнсько-польського семін ру. мбір, 15-18 вересня 2011 р.). - ьвів : імені в н р нК, 2011. - .69-78.

3. огуиький . порний розріз ружики н ністрі: співвідношення люві льних, льодовикових i покривних товщ плейстоцену / . огуцький, . нчонт, . цишин т ін. // ляці л і перигляці л кр їнського ередк рп ття : зб. н ук. пр ць (до V укр їнсько-польського семін ру. мбір, 15-18 вересня 2011 р.). ьвів : $\quad$ імені в н р нК, 2011. - .79-86.

4. огуцький . порний розріз убрівк : льодовиковий комплекс, лесовий покрив, дольодовикові відкл ди / . огуцький, . нччонт, . цишин т ін. // ляці л і перигляці л кр їнського ередк рп ття : зб. н ук. пр ць (до V укр їнськопольського семін ру. мбір, 15-18 вересня 2011 р.). - ьвів : імені в н p нк , 2011.- . 87-96.

5. огуцький . порний розріз лохині: льодовикові відкл ди, тер си, лесові покриви, п леоліт / . огуцький, . нчонт, . цишин т ін. // ляці л і перигляці л кр їнського ередк рп ття : зб. н ук. пр ць (до $\mathrm{V}$ укр їнськопольського семін ру. мбір, 15-18 вересня 2011 р.). - ьвів : імені в н p нК , 2011. - .97-105.

6. офштейн . . еотектонік і морфогенез ерхнього ридністров'я / лля видович офштейн. - .: ид-во , 1962.-131 с.

7. емедюк . . ревние поверхности выр внив ния кр инских рп т / . . емедюк // еоморфология. - 1982. - № 3. - . 36-44.

8. емедюк. . оверхности выр внив ния кр инских рп т и их предгорий / . . емедюк // Studia Geomorphologica Carpatho-Balkanica. - 1983. - Vol. 16. S. 3-14. 
9. ерж вн геологічн к рт кр їни, м сшт бу $1: 200000$, ркуші -34( шемисль), -34- V ( рогобич). рп тськ серія. - . : ерж вний комітет природних ресурсів кр їни, “ др кр їни”, хідукргеологія, “ ьвівськ геологорозвідув льн експедиція", 2005.

10. $р$ вчук. еоморфологія ередк рп ття / росл в р вчук. - ьвів : ерк тор, 1999. - 188 с. - ( ельєФ кр їни).

11. $р$ вчук. оверхні вирівнюв ння в кр їнських рп т х: 3 кономірності поширення, мех нізми формув ння, кореляція з генезисом і віком / . p вчук // роблеми геоморфології і п леогеогр фії кр їнських рп т і прилеглих територій : зб. н ук. пр ць ( орохт , 6-9 вересня 2012 р). - ьвів : імені в н р нк , 2012. - .41-52.

12. узовенко. . тчёт по теме: “ зучение опорных $\mathrm{p}$ зрезов мезок йнозойских отложений юго-з п дной окр ины осточно- вропейской пл тформы, редк рп тского прогиб и северного склон кр инских рп т, сост вление стр тигр фических схем и легенды для крупном сшт бных геолого-съёмочных р бот”, 1983-1985 гг. - .3. р фические приложения, зрез № 31: юго-з п дный склон г. дыч. - ьвов, 1985.

13. убцов . . еологическ я к рт м сшт б $1: 50000$. исты -34-94( обромиль). -34-95- ( мбор), -34-95- ( удки) / . . убцов, . . ис ренко, . . окуров / онды ьвов. геологор зв. экспедиции. -1971.

14. убцов . . тчёт мборской геолого-съёмочной п ртии з 1965-1971 гг. / . . убцов, . . ис ренко, . . окуров / онды ьвов. геологор зв. экспедиции. $-1971 .-$ н. $2 .-620$ с.

15. цишин . т пи формув ння т геоморфологічн будов долини р. тривігор у меж х ередк рп ття / . цишин, . огуцький, . лотніков // iсн. ьвів. ун-ту. ер. геогр. - 2008. - ип. 35. - . 348-360.

16. цишин . сновні ет пи верхньопліоцен-нижньоплейстоценового морфо-, літогенезу долини ністр у р йоні лицького ридністер'я / . цишин // iсн. ьвів. ун-ту. ер. геогр. - 2010. - ип. 38. - . 379-394.

17. цишин. т пи морфогенезу північно-з хідної ч стини долини ністр / . цишин, . огуцький, . олуб т ін. // ляці л і перигляці л кр їнського ередк рп ття : зб. н ук. пр ць (до $\mathrm{V}$ укр їнсько-польського семін ру. мбір, 15-18 вересня 2011 р.). - ьвів : імені в н р нК , 2011. - .29-61.

18. Eanczont $M$. Zapis interglacjalno-glacjalnych cykli w sekwencji osadowej w Kru ykach nad Dniestrem (wschodnie Podkarpacie) / M. Łanczont, A. Bogucki, P. Mroczek [i in.] // Annales UMCS, Geographia, Geologia, Mineralogia et Petrographia. - Lublin : Wydawnictwo Universytetu Marii Curie-Sklodowskiej, 2010. - Vol. 45, 2. - S. 37-55.

19. Teisseyre H. Problemy morfologiczne wschodniego Podkarpacia / H. Teisseyre // Sprawozdania Polskiego Instytutu Geologicznego. - 1933. - T. 7, z. 3. - S. 421-454.

20. Teisseyre H. Czwartorzęd na przedgórzu arkuszu Stary Sambor / H. Teisseyre // Sprawozdania Pol. Tow. Geol. - 1935. - T. 8, z. 2. - P. 67-81.

21. Teisseyre H. Czwartorzęd na przedgórzu arkuszy Sambor i Dobromil / H. Teisseyre // Rocz. Pol. Tow. Geol. - 1938. - T. 13. - S. 31-81. 


\title{
STRUCTURE AND FORMATION HISTORY OF THE PLANATION SURFACES OF THE NORTH-WEST FORECARPATHIANS
}

\author{
Andriy Yatsyshyn \\ Ivan Franko National University of Lviv, \\ P. Doroshenko Str., 41, UA - 79000 Lviv, Ukraine
}

Based on the detailed geomorphological analysis of the terraces of the Dnister River, and of its tributaries, and the analysis of the sections of the terrace deposits, the main stages of the history of the Dnister valley development in the north-south Forecarpathians have been presented. Some existing and already firmly establishes opinions concerning the structure of the terraces, their extent, and the time of their formation were clarified. The paleogeographical events were correlated with the stages of the oxygen isotope scale, the paleomagnetical reference points and the paleogeographical (paleoclimatical) phases.

Key words: Krasna planation surface, Loyeva planation surface, Starosilska planation surface, terrace, surface of the terrace, plinth (socle) of the terrace, alluvium, glacial deposits, absolute and relative datum levels. 